\title{
Conquering Land, Conquering Women: Exploring the Co-relation between War and Sexuality in the Early Medieval Indian Inscriptions
}

\author{
Shatarupa Bhattacharya
}

\begin{abstract}
What does victory mean? Is it access to resources? Then the corollary question would be what kind of resources. Is it human or material resource? Many a times the line between the two blurs in early India. The ruler in the description of their war exploits mention access to men and women besides land and materials. Another way would be to use similes which would reflect the co-relation between the two. Why and when sexual access to women becomes the norm for the victor? Publicising sexual access to women during war through inscriptions was a common practice in the early medieval period in Indian history. Concepts such as beauty, sexuality and cultural refinement besides bravery become part of the newly emerging courtly culture. Attempt in this paper is to explore the thread correlating courtly culture, sexuality and war through epigraphs.
\end{abstract}

Index Terms-Courtly culture, inscriptions, sexuality, violence.

\section{INTRODUCTION}

War throughout history can be gauged by the number of people who had died. These statistical details are well available and corresponding to it are the details of women raped or kidnapped. The question that arises is why sexual exploitation is seen as a part of war culture? And from where do we trace its beginning. Has sexual control or access to women always been the norm? I start with the well known and implicitly acknowledged fact that victory in war is represented in the persecution of women. Sexual exploitation of women after victory was best dramatised in the Mahābhārata, an early Indian epic, in the dice game where victory was sexual access to the queen, Draupadi. In a way, war can be perceived as gendered in nature. The experience of war is different for men and women.

One can also notice how violence against women (here reference is not only to physical violence) has a distinct sexual connotation. The effect of war on women has sexual overtones as victory over them has to be implemented by access to her sexually or owning her physically.

Gerda Lerner has pointed out in her work that women had been commodified since the Neolithic times [1]. The reproductive potential of women has been pointed out by scholars as one of the main factor of objectifying women. The social control over women's reproduction had become

Manuscript received September 5, 2014; revised December 23, 2014 This work is in part supported by Indian Council for Historical Research, Delhi, India.

Shatarupa Bhattacharya is with the Lady Shri Ram College, Delhi University, India (e-mail: shatarupa.b@gmail.com). essential for existence and sustenance of patriarchy. LéviStrauss explains the origin of women's cultural subordination in terms of the 'exchange of women' [2]. Gerda Lerner further adds that women's sexuality and reproductive capabilities were the main basis of exchange. Thus men start viewing women as their possession and see them primarily as sexual objects for their own gratification [2]. This would explain violence against women with its various manifestations to an extent.

In description of war in epigraphs, a gendered pattern can be noticed, for men it is to suppress them physically, the reference is to trample, cut, lost crowns, bowing of head etc. whereas for women it's tears, tremor, breasts, enjoying her sexually, marriage etc. Women are only seen as a sexual being. Their description, be it in part of war details or to show king's virility is basically physical. Interestingly the king was also in many of the inscriptions described as beautiful and virile and how women get intoxicated by his 'manliness.' So sexuality was important for both but what seems to be a quality for one becomes the point of access for other. In eulogizing rulers for their various victories his control or access to women belonging to the enemies is described. This trend gains a momentum more specifically from the early medieval period in the Indian history.

It is generally believed that war or particularly invasions bring about change in the status of women throughout history. The change is specially seen in terms of her been objectified. Protecting women or exploiting her becomes the norm for a 'civilised' society. Victory over women was probably seen as control over the sexual potential of the society. Therefore exploiting women would be harming what mattered most. That would explain to some extent the violence against women during or after war. What seems interesting from a historical point of view is how women's sexuality has been portrayed in the description of the war exploits of kings. Here they not just mention victory but provide a sexual description of that victory over women.

Inscriptions show how warfare and victory has been proclaimed by rulers. The inscriptions, especially those which belong to the early medieval period, the king or the donor of the grant gave descriptive details about the king's victory. The victory described is in terms of his conquest over men as well as women. For women the description not just ends at her tears but includes sexual description. Inscriptions of the early period however, do not refer to the sexual access or violence rather describes it in terms of fear. The trend goes through a change in the early medieval period where access to women sexually is described or is intended. Does the sexual description of women as part of victory campaign is to 
satisfy the voyeuristic desires? One can also question the probable reasons for such a transformation in the inscriptional records which were in the public domain.

The aim of the present study will be to look at the early medieval inscriptional evidences which describe the sexual pleasures derived from women or sexual description of women in the genealogical part of the inscription. Why such a change in terms of description of sexuality in inscriptions could be seen in the early medieval times? Is it linked to the emerging courtly culture? Is it linked to objectifying women as land and the king's ownership over it? Does the complex stage of influx which the early medieval period sees can explain the growing concern over the portrayal of sexuality? Will that explain why sexual violence towards women was commemorated in inscriptions? In the present study an attempt will be to understand and explore some of these questions.

\section{CONTEXT}

The early medieval period in Indian context, saw a change in terms of newly emerging centres of power and also in terms of new courtly culture. This period saw emergence of the Sanskrit literature as epitome of culture. Noticeable changes can be seen in textual, inscriptional and in all cultural spheres. Thus a change in the social values and ethics of the time can be talked about. This transformation has been discussed in terms of various political, economic and social changes that one can notice during this period. Sanskrit was an administrative as well as a literary medium. Most of the inscriptions were recorded in Sanskrit and this period can also be seen as epitome of Sanskrit literature. From the Gupta period onwards i.e. 5th century CE, work in Sanskrit was patronized by the ruling class and soon it had become part of the courtly culture.

With the coming of the kāvya traditions, emphasis has now shifted to erotic poetry. The inscriptional record refers to the concept of beauty for the elite. Physical beauty has become prominent aspect of the royal lineage. Time and again the king was compared to the Moon and also to Cupid. Sexual control over women at the same time has become all the more prominent. Time and again one finds references to enjoying women or having access to them sexually. The courtly culture is well represented in these kāvya traditions. The emphasis is on beauty, refinement and culture, best represented in the concept of 'nāgaraka' (an urban man) in literary text such as the Kāmasūtra.

The inscriptional records of this period again saw a major transformation. The purpose of the records was not just to enumerate details of the land grant or otherwise, rather had become an important tool of legitimization. The epigraphs were, as Daud Ali calls 'inscriptional kāvyas', i.e. they were treated as a piece of literary work [3]. The poets mentioned in inscriptions claimed a reputation. The relation between the patron and the poet is well discussed and criticised upon in other literary texts but at the same time was considered as prominent. With the growing importance of poets and the court culture, a change can be noticed in the way women were now dealt with in the records.

Notably this period is one of agrarian expansion as can be seen from the spurt of land grants from around 6th century CE. Owning land and controlling it was another important feature of this period. This is a period when various dynasties were fighting over land. Hence what becomes fascinating is the allegory used to represent land as women and king's right to own it. In Sandhyākāranandin's Rāmacāritam, Sitā is not a human rather the land, Virendri (north Bengal) which was lost and then regained by the king Rāmapāla [4]. Thus the ruler was the 'lord' and land was described as wife of the lord. Roy understands it as a tendency to objectify women and in terms of kingship coterminous with ownership [4].

Textual sources enumerate the role of war and violence associated with kingship in many ways. Danda was an important aspect and feature of kingship. King was feared and respected because of the divine sanctioned right to punish. The most prominent power of the ruler was his ability to punish. According to the Gautama Dharmasūtra, the word danda was derived from the root dam that meant to control [5]. The king should be in command of people by exercising danda. Thus the king had the divine sanction and could justify violence. Since he was the lord he had access to all resources which later specifically included women besides land. The Kāmasūtra also mentions the right of the ruler over the wives/ women of others which could be understood in terms of power relation and lordship.

What I intend to explore is how this change in the literature had an impact on the way women were represented. With the kāvya literature, enjoyment has a new meaning; the emphasis is on sexual expertise. The notion of women as objects of desire probably gained a stronghold during this period. A description of war exploits in the inscriptions thus mentions in most cases what effect it had on women of the vanquished. I am not referring to the queens or other elite women who were mentioned as donors or wife or mother of the donor. I am referring to women who are casually described in the genealogical section as poets described the war exploits of the king. How sexuality of women has been a component of description of war exploits and the king's publicized claim over women of his enemies. Again this control was to an extent similar to controlling/owning land.

\section{UNDERSTANDING SEXUALITY}

Sexuality has been understood as a cultural phenomenon by scholars. Sexuality was again defined and understood from a patriarchal lens. It had been understood by earlier scholars as stable and universal. But recent scholars believe that sexuality differed not only in terms of period and region but also in terms of gender. As Shalini Shah has mentioned, 'The content of sexuality, its experience, and its institutional forms are highly variable' [6]. Catherine MacKinnon writes, 'sexuality is to feminism what work is to Marxism; that which is most one's own, yet most taken away' [7]. Sexuality in itself is based on unequal social relations. Therefore Shalini Shah opines that the social control of women through sexuality was the result of gendered inequality. Women are objectified and patriarchy plays an important role as the social mechanism through which women are subordinated. The 'libertarian' feminists, however, emphasize on the theory of pleasure. According to them by mentioning only 
violence and oppression, women's agency in terms of pleasure and gratification is ignored [6].

In the Indian context, scholars have used texts such as the Kāmasūtra which is believed to be the best manual on the subject. It was a text which codified kāma or desire as a subject and also gave it legitimacy as a śāstra [8]. But again the text is male-centric therefore the understanding of sexuality has been gendered. The text is prescriptive as well as normative. The aim of the text was to regulate sexuality and at the same time sanction it as natural. Ancient and Medieval Indian texts, unlike earlier scholars writing on it, understood pleasure neither as part of the natural human biology nor as part of a subjective, inner or private world. Pleasure was understood as a cultivated practice [9].

Women are observed as tools and as objects to be used and enjoyed. Role of the 'nāyikā' is well explained in the Kāmasūtra but the centre stage is occupied by the 'nāyaka.' The power relation between desire and being object of desire is central to the text [8]. The text also invariably sanctions violence which women had to endure.

\section{VIOLENCE AND WOMEN}

Violence is a symbolic language. Nessan defines violence as, '...the attempt of an individual or group to impose its will on others through any non-verbal, verbal or physical means that will inflict psychological or physical injury' [2]. Patriarchy, as an ideology and structure of domination, justifies violence. In the private sphere of the family, patriarchy exerts its violent power through social control of women. By controlling women's access to education, economic resources and through blaming and shaming, violence becomes what has been referred to as 'social surd' by Bernard Lonergan [2]. In a way, being violent was socially accepted and women were trained to understand and undergo violence in its various forms. Violence can be physical or psychological, but overall it plays an important role in undermining women's position in the society.

The inscriptions also present a very useful source to understand war history and the concept of violence sanctioned by state. Despite its disadvantages as a source, it opens new ways to understand and perceive society. The early medieval period is known for the foray of inscriptions, although most were elite in nature. The best example is provided in the form of inscriptions which besides giving details of the grant also enumerates and eulogizes the family of the donor. In this case we are specifically referring to grants by kings. It is interesting to note how violence not just has a social sanction but is part of the eulogy. Violence is justified and accepted as the norm. Daud Ali in his work has sought linkage between violence and aristocratic elites and social transformation. He tries to understand it in terms of what he calls 'courticization' of the warrior lineages [3]. Although he is not using a gendered lens but his study is useful in understanding changes in the early medieval period. He mentions how it was not just reference to violence but at the same time gentleness which had become an important characteristic of the elite by the early medieval period. With emerging centres of power, violence is both justified and at the same time fluidity could be noticed as one finds reference to gentleness or allegory to kindness mentioned in records.

\section{WOMEN, WAR AND EPIGRAPHS}

I have looked at some of the inscriptional records, and tried to understand gendered nature of violence. I have attempted to look at the various ways in which women's sexuality has been mentioned as part of war exploits in the genealogical part of the inscription. My main concern is the notion of access to women in war descriptions. However, I am not looking for details of how women in general had been described in the epigraphs.

There were distinct trends in the way women were described in the war exploits. Some directly refer to access to women and that war represented the best platform for that. Some refer to controlling land but reference is in voyeuristic terms. Besides some later inscriptions mention how was king was different as he was not exploiting women of his enemies like other rulers. Besides, some just mentions how women of their enemies pined for the victor ruler. In a way, inscriptions besides being an administrative tool also have functions similar to poetry i.e. satisfying desires of the patron. It reiterates the sexual roles i.e. one who desires and one who is desired. The role of the epigraphs in establishing court culture has been mentioned by scholars. These voyeuristic descriptions show how women's sexuality has become the foreground to king's hegemonic masculinity.

The purpose of war was not just control over land but was also over women is best represented in the Sanjan Plates of Amoghvarsa I, Śaka Samvat 793 i.e. 871 CE [10]. In the genealogical record, the inscription mentions Indraraja who seized the daughter of the Câlukya king in the battle by rāksasa form of marriage (verse 7). According to the Dharmaśāstras this was considered the last one of the eight forms of marriage and was equivalent to rape in modern terminologies followed by marriage. Further in verse 10 again the record mentions how another king, Krishnā I also forcibly seized the Cālukya sovereignty. The verse records that battle-field proved a place of choice of marriage.

Most explicit reference to enjoying women as part of war exploits comes from the Bilhari Stone inscription of Yuvarajadeva II, 975 CE [11]. In verse 22, Mugdhatunga or Prasiddhadhavala was described as thinking about women of Kerela as his army camped near the sea besides a gory description of his victories. In verse 24, Keyuravarsha or Yuvarājadeva I was described as, '...one who fulfilled the ardent desires of the minds of the woman of Gauda, who sported on the breasts of ladies of Karnậta even as a deer does on a pleasure-hill; who applied the ornamental mark to the forehead of the woman of Lạta; who enjoyed the pleasures of love with the woman of Kāśmira, (and) was fond of the excellent songs of the woman of Kalinga.' Mirashi interprets it as marriage with women of these countries [12]. But very clearly marriage does not seem to be the motive here. Clearly it shows how the king claimed his sexual access to women of various regions.

The Kālanjar stone inscription of Paramardin (vikrama) year 1258 i.e. $1201 \mathrm{CE}$ verse 25 describes king Paramardin of Candellās of Jejakbhuktias, as one who sought pleasure in the company of women [13]. 
In the Tiruvalangadu inscription, (a Telugu chief), dated Śaka 1129 i.e. 1207-08 CE, mentions that the king Dāyabhima, hands was reddened by pulling the hair of the goddess of royal fortune belonging to (his) enemies and now he ruled the earth [14]. Explicitly, violence against women had become a facet of kingly power.

The Sravana-Belgola inscription of Irugapa, $1422 \mathrm{CE}$, of Vijayanagara dynasty, General Mangapa in verse 5 was described as one who, '...took away the necklaces from the broad breasts of the wives of his adversaries...' In verse 17, Irugapa was eulogized as, '.. while the world was made white by the fame of the general Irugapa, blackness was praised only in (connection with) the hair of (women) with rolling eyes, while his bar-like arm was wearing the bracelet of the earth, mutual oppression also was spoken of only in (connection with) their breasts.' According to the verse 18, women were described as, 'by their ears with their ear-rings forgotten, by the surfaces of their foreheads with no marks fixed to them, by their dishevelled curls, by their swelling breasts untouched by strings of pearls, and by their bimba-like lips deprived of the redness (caused) by the betel, even the fair-eyed (wives) of the kings hostile (to him) repeatedly (and) thoroughly betray his excessive power' [15] Explicitly the voyeuristic pleasures derived from such poetic descriptions of violence point to the objectification of women. King's exploits in a way must mention control over women. The record also mention that women were by nature disloyal, freckle minded and they should be controlled, if required with force.

In many inscriptions the relation between women and land as an allegory is well used. The concept of women as property that could be owned and controlled becomes the recurrent idea. The Valabhi grant of Dhruvasena III, Samvat 334 i.e. 653-54 CE, of the Rāṣtrakụtas in verse 29 describes the exploits of Dharasena as one, '....who gave great delight to the earth, as to a maiden, by imposing light taxes (or by taking her soft hand); who with his bow, seemed to be (an incarnation of) the science of archery, as he hit all sorts of aims, and whose commands resembled the crest jewel which were ...(worn) on the heads by the crowd of his bowing vassals.' In verse 36 Dhruvasena was described as one who, '... wore bright fame as a white garment, and which handed to him the splendour of royalty as the garland at a "self-choice" (svayamvara); who in autumn, depending on his valour which was as irresistible as his sword, that had subdued the territories of fierce enemies, has lawfully taken the hand of (pānigrahan) [or levied taxes from] foreign countries, which were conquered...' [16]. Thus control over land was described in same way as marriage. Again lordship was hinted and control over land was seen in terms similar to access over women.

The Cambay Plates of Govinda IV, Śaka 852 i.e. 930 CE of the Rāștrakụta dynasty describes Jagattunga in verse 11 as one whose princely enemies, deprived of the extent of all their territories, were like the breasts of women destitute of the youth, i.e. which have lost their plump circumference. Govindarāja in verse 25 was eulogized as one on whose victory the earth with uplifted hands took the pālidhvajas (victory flag) and abandoned other kings [17]. It was seen similar to a woman, when freed, from an evil lord, dances with joy and excitement with uplifted hands.

The Gadval copper plates of Vikramāditya I, $674 \mathrm{CE}$, refers to a grant of land at the request of queen Gangā Mahādevi. In this record the king Vikramāditya's war exploits were mentioned, in verse 4 which describes him as one, '... who became the favourite of fortune (Śrivallabha) in a still higher degree, though (at the same time) forcibly wooing the damsel 'Southern region' by seizing (her) girdle: (the city of) Kāñchi, while (he) caused to be crushed the sprouts (forming her couch); the Pallavas (king)... [18]Interestingly, the king's ravages on the city of Kãñci were described in terms of his forcefully imposing his power on women.

The Two grants of Indrarāja III, Śaka 836 i.e. 915 CE, in second grant eulogizes Indra III as one, '...the hand (i.e. the prowess) of this (prince), matchless in battle, having (first) established itself on the beautiful lowermost region of the earth, and having again overcome in a gentle manner at its own will the central region (Madhyadeśa), again established itself in the province of Kāñchi, just as the hand (of a lover) after (first) establishing itself on the hips of a women, attractive to heart, and pressing again gently at its will (her) waist, again establishes itself on the region (below the waist) where the girdle (is worn)' (verse 6) [19]. Again sexual access to women and earth is compared here.

The Rewa stone inscription of Karna, year 800, i.e. 1048-49 CE of the Kalacuri dynasty (Tripuri branch) in verse 25 mentions Karna as having over-run the districts of Kāñci, he enjoyed the southern region, the fortunes of Kuntala were shaken and Pallavas were destroyed. The poet has used words in such a manner that the verse could also be understood as in terms of a woman. The verse can be translated as, '... as though covering the hips of a woman he was ravishing her, the beauty of whose hair was marred by forcible seizure, and whose tender lower lip was wounded in kissing.' Further in verse 27 it mentions that, 'When he approached, tears mixed with collyrium flowed on the cheeks of Gurjara women living in the neighbourhood, and colour-marks indicative of their non-widowhood slipped, as it were, from (their) foreheads' [20] Again access to women sexually and violence seems intertwined in these descriptions.

The Akaltara stone inscription of Ratnadeva II, 1141-42 $\mathrm{CE}$, of the Kalacuri dynasty (Ratnapur branch), donor Vallabharāja mentioned earth as the crowned queen of his lord Ratnadeva II in verse 21 [21].

Some inscriptions mention noble kings who claim that they did not exploit women of their enemies and therefore were different from other kings.

The Two inscriptions of the Vaillabhattasvāmin temple at Gwalior, dated year $932 \mathrm{CE}$ where the donor, officer of the fort mentions in verse 15 that Alla (the donor) although avoided the wives of others [22]. Thus he was capable of desiring women of other rulers but refused to exploit them. In a way the donor was not less 'kingly' in his desires but choose the other way. It is an interesting insight into the courtly culture and how access and control over women was an inherent feature of kingship.

The Two Praśastis of Baijnāth, king Lakshmannacandra lauds over the fact that he unlike others do not think that, 
'...the sovereignty over a town to yield its legitimate result only by the rape of wives of the inhabitants' (verse 24). In verse 26 mentions that, '...the hand of this pure-minded Rājanaka which is expert in wielding the sword, has (since) avoided (Buhler holds that the king according to the prefect used, did this praiseworthy conduct after his pilgrimage to Kedarnath) the blameable pressing of the bosoms of the wives of others [23]. Again it clearly mentions how sexual exploitation was the norm and some king marked a difference. This may be a move towards refinement and gentleness which was gradually becoming a noticeable quality of a king.

Some of the inscriptions do not have an explicit allegory or mention sexual access to women but at the same time the descriptions in the records are worth a notice. The Chiplun copper plate grant of Pulikesin II of Cālukya dynasty has an interesting description of king's manliness. It describes how '...Laksmi (goddess of fortune) looks at him like husband, similarly women of Kinnaras also look up to him as husband,...(king) whose besmearing with sandal-wood oil is rubbed off by the (clinging of) the bulky breasts of the goddess of fortune'. Further the record mentions that the king as, '...the sole aim of the arrows which are the eyes of nice young women' [24]. The Kahla Plates of Sodhadeva, (vikrama) year 1135 i.e. $1079 \mathrm{CE}$ of the Kalacuris of Saryupara, king Ullabha was described as, '...barbed arrow in the hearts of multitude of enemies' wives; at the sight of whom the tie of the girdles of (ladies), who had tremulous deer-like eyes suddenly became loose...' (Verse 11). In verse 15 king Bhāmānadeva I was compared to moon to the lotus plants which was the face of the enemies' young wives. Further the verse mentions that during his reign the tears flowed incessantly through jealousy from the eyes of the wives of the Vidhyādharas as he had control over the goddess of fortune [25]. The Ratnapura stone inscription of Jajalladeva I, year 866, i.e. $1114 \mathrm{CE}$ belonging to the Kalacuris of Ratnapura, in verse 20 Jajalla I's fame was described as hundreds of women fallen in love with him. Further verse 25 mentions that the earth with her uplifted arms proclaimed as a noble, valorous and serene. He was described in the next verse as the beautiful god of love not seen by Śiva or as Vịnu with Śri [26].

The correlation between objectification of women and courtly culture seems to be a recurrent theme in description of king and his exploits in inscriptions.

\section{CONCLUSION}

This is a preliminary attempt to study the relation between women, war and sexuality. MacKinnon in her work says that sexual objectification of women leads to her subjection. Sexuality is understood in terms of politics which undermines position of women in a society. Through art and aesthetics women are objectified and her role in a society is determined. These can be seen as one of the method or process of socialization which 'constructs' the imagery of a 'women.' Sexuality has been understood from a men's point of view i.e. women should be attractive and desirable to men. Her existence was defined in terms of her role in fulfilling men's desire. Through inscriptions one can perceive that objectification of women has been part of court's culture.
Being elite would mean a refined way of describing women's sexuality. She is the object to be desired, owned and also displayed. This commodification can be observed in inscriptions which made women not just objects of control rather sexual objects that can be owned. The court has a major role to play as the courtly culture which is represented in the kāvya tradition refers to women as objects. It is interesting that the records, which besides many purpose, has a role in legitimizing kingship, mentions or rather celebrates violence against women. The violence is more in terms of objectifying women and her sexuality. Kings are not just known for their victory over other kingdoms rather over women of their enemies. Having sexual access to women and enjoying her can be nuanced but objectification seems a common thread. Women were objectified as land something which can be won, accessed and controlled. And king was the overlord of women as well as land. The king's masculinity was enhanced by his control or access to women through war. In the public declaration of his exploits one can see the power that he claims over women. This control was described as sexual as sexuality was a method of legitimization for the ruling elite.

\section{REFERENCES}

[1] G. Lerner, The Creation of Patriarchy, New York: Oxford University Press, 1987, p. 212.

[2] S. Rakoczy, "Religion and violence: the suffering of women," Agenda, Religion \& Spirituality, no. 61, pp. 30-31, 2004.

[3] D. Ali, Courtly Culture and Political Life in Early Medieval India, New Delhi: Cambridge University Press, 2006, p. 18.

[4] K. Roy, "The Artful Biographer", in the Power of Gender \& the Gender of Power, K. Roy Ed., New Delhi: Oxford University Press, 2011, p. 368.

[5] P. V. Kane, History of Dharmaśāstras, Poona: Bhandarkar Oriental Research Institute, vol. 3, 1973.

[6] S. Shah, Love, Eroticism and Female Sexuality in Classical Sanskrit Literature: Seventh- Thirteenth Centuries, New Delhi: Manohar, 2009, p. 37 , pp. $40-41$.

[7] C. A. MacKinnon, "Feminism, Marxism, method, and the state: An agenda for theory," Signs, vol. 7, no. 3, pp. 515-544, 1982.

[8] K. Roy, "Unravelling the Kāmasūtra," in the Power of Gender \& the Gender of Power, K. Roy Ed., New Delhi: Oxford University Press, 2011, pp. 325-326.

[9] D. Ali, "Regimes of pleasure in early india: a genealogy of practices at the cola court," Ph.D. Dissertation, University of Chicago, Illinois, 1996 , p. 30.

[10] Epigraphia Indica, Reprint, vol. 18, 1983, pp. 235-257.

[11] Corpus Inscriptionum Indicarum, V. V. Mirashi, Inscriptions of the Kalachuri-Chedi Era, Ootacamund, 1955, vol. 4, no. 1, pp. 204-224.

[12] Corpus Inscriptionum Indicarum, V. V. Mirashi, Inscriptions of the Kalachuri-Chedi Era, Ootacamund, 1955, vol. 4, no. 1, p. 206.

[13] Corpus Inscriptionum Indicarum, H. V. Trivedi, Inscriptions of the Paramaras, Chandellas, Kachchapaghatas \& Two Minor Dynasties, New Delhi, 1991, vol. 7, no. 3, pp. 478-482.

[14] Epigraphia Indica, Reprint, 1981, vol. 7, pp. 119-126.

[15] Epigraphia Indica, Reprint, 1981, vol. 8, pp. 15-24

[16] Epigraphia Indica, Reprint, 1983, vol. 1, pp. 85-92.

[17] Epigraphia Indica, Reprint, 1981, vol. 7, pp. 26-47.

[18] Epigraphia Indica, Reprint, 1984, vol. 10, pp. 100-106.

[19] Epigraphia Indica, Reprint, 1981, vol. 9, pp. 24-41.

[20] Corpus Inscriptionum Indicarum, V. V. Mirashi, Inscriptions of the Kalachuri-Chedi Era, Ootacamund, 1955, vol. 4, no. 1, pp. 263-275.

[21] Corpus Inscriptionum Indicarum, V. V. Mirashi, Inscriptions of the Kalachuri-Chedi Era, Ootacamund, 1955, vol. 4, no. 2, pp. 430-436.

[22] Epigraphia Indica, Reprint, 1983, vol. 1, pp. 154-162.

[23] Epigraphia Indica, Reprint, 1983, vol. 1, pp. 97-118.

[24] Epigraphia Indica, Reprint, 1979, vol. 3, pp. 50-53.

[25] Corpus Inscriptionum Indicarum, vol. 4 V.V. Mirashi, Inscriptions of the Kalachuri-Chedi Era, Ootacamund, 1955, no. 2, pp. 382- 397.

[26] Corpus Inscriptionum Indicarum, V. V. Mirashi, Inscriptions of the Kalachuri-Chedi Era, vol. 4, Ootacamund, 1955, no. 2, pp. 409-417. 


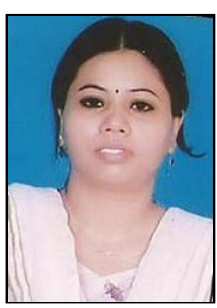

Shatarupa Bhattacharya was born in Delhi, India on November 9, 1976, who has graduated in history from Miranda House, Delhi University in 1998. She completed her post graduation with specialization in ancient Indian history in 2000. Then she received her M.Phil from Jawaharlal Nehru University (JNU), Delhi in 2002. She was awarded PhD \{Topic: Representation of Gender Relations in Early Medieval Puranic Traditions and Central Indian Inscriptions $\left(4^{\text {th }}-12^{\text {th }}\right.$ century) $\}$ in 2010 from JNU, Delhi.
She has been teaching undergraduate students in Delhi University as an assistant professor. Presently she is teaching in Lady Shri Ram College, Delhi University, Delhi. Recently her article on 'Issues of power and identity: Probing the absence of 'mahārājñ̄i'. A survey of the vākạtaka inscriptions' was published in Indian historical review, June 2014. Another article 'Perceiving gender through genealogy: A study of the vākātakas' published in proceedings of Indian history congress, $68^{\text {th }}$ session, Delhi, 2007. Her research interests include gender studies in early Indian history.

Dr. Shatarupa Bhattacharya is a member of Indian history congress, India. 